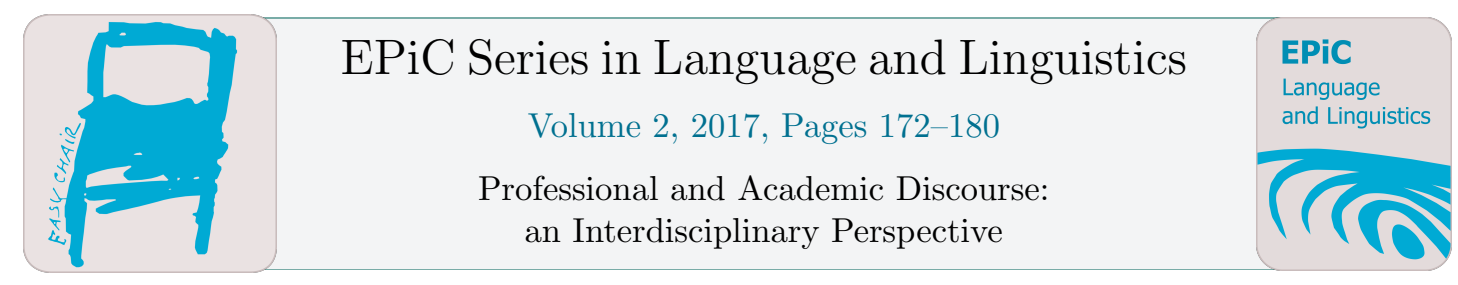

\title{
Spanglish in Piña-Rosales’ Modern-day “Don Quijote en Manhattan”
}

\author{
Ricard Morant ${ }^{1}$ and Debra Westall ${ }^{2}$ \\ ${ }^{1}$ Universitat de València (Spain) \\ ${ }^{2}$ Universitat Politècnica de València (Spain) \\ ricardo.morant@uv.es,dwestall@upv.es
}

\begin{abstract}
This research aims to contribute to our understanding of Spanglish, namely by examining Gerardo Piña Rosales' short story “Don Quijote en Manhattan” (2006). Through a close analysis of this expressive modality, particularly the use of Spanglish by the character of Sancho in his encounters with the city's other inhabitants, including tourists, homeless, small-time criminals and police, we are able to gain insight into the reality of modern-day language contact in a truly contemporary setting. The paper is organized as follows. First a brief review of the most recent Spanglish research is offered, then we describe the materials and method used for this study, and finally we propose a classification of Sancho's Spanglish.
\end{abstract}

\section{Introduction}

The aim of this research is to examine the Spanglish used in the short story "Don Quijote en Manhattan”, written by Gerardo Piña Rosales (2006). In line with Dumitrescu (2013 and 2015), Betti (2015) and López García-Molins (2015), we consider that Spanglish is 'an enormously complex phenomenon' (our translation, Dumitrescu, 2013: 355), and by analyzing examples in the story, both academics and professionals can better understand the characteristics of this expressive modality. In the story, the author portrays the adventures of a modern-day Don Quixote (aka Ergardo or Heraldo or Torres, Spanish by birth, exiled to New York) and his loyal squire, Sancho (aka Edwin Rivera, born in Puerto Rico, raised in the Bronx) who, over the course of two days, travel the length and breadth of Manhattan in search of opportunities to fight for justice.

This paper focuses, therefore, on one particular case of language contact, that of Spanish and English among Puerto Ricans in New York, and on the very particular case of the Spanglish spoken by Sancho with Don Quijote and the city's myriad inhabitants (tourists, homeless, small-time delinquents and cops, among others). In her book Growing Up Bilingual: Puerto Rican Children in New York (1997), Ana Celia Zentella, expert in bilingualism in this city, affirmed: 
En contra de lo que muchos creen, el spanglish es un signo de destreza lingüística. [...] El code switching lo utilizan no sólo los inmigrantes de clase baja de El Barrio, sino también sus hijos acomodados que trabajan en Wall Street. [...] Las nuevas generaciones de latinos, los nacidos aquí, se manejan mejor en inglés que en español, pero antes que resignarse a perder su segunda lengua materna, la incorporan espontáneamente a su discurso. Es un modo de reafirmar su identidad. (Zentella, 1997, cited in Betti, 2008: 14)

Therefore, for Zentella (1997, cited in López García-Molins, 2015: 37), Spanglish refers to “[...] the conversational and communicative strategies of bilingual Puerto Rican New Yorkers, and more concretely, to the bilingual practice of inserting phrases and sentences in English into Spanish discourse, or vice versa." ${ }^{1}$ Additionally, Otheguy and Stern (2010: 96) pointed out that "Spanglish [...] is not intended as the name of a hybrid language, but rather, that it refers to a way of using the languages". More recently, López García-Molins (2015: 48, citing 2013b²) goes further to insist that "Spanglish is not a new language which results of mixing two preceding languages. It is a linguistic behavior supported by the knowledge of two languages and the wish to put them together.”

In recent years Spanglish has received much attention, especially from linguists, many tending to adhere to one of two visions of this phenomena, ${ }^{3}$ as reported by Dumitrescu (2014):

[...] para algunos, es equivalente básicamente al code-switching, o sea a la alternancia entre el español y el inglés en la interacción verbal entre bilingües (que en principio no solo que no está estigmatizada, sino que goza de cierto "prestigio encubierto" entre muchos hispanounidenses). (Dumitrescu, 2014: 27)

[...] para otros es más bien una variedad de español plagada de anglicismos (préstamos léxicos, calcos fraseológicos y extensiones semánticas) innecesarios, que dificultan, hasta obstaculizarla a veces del todo, la comunicación con un hispano monolingüe de otro país, y que sí está fuertemente estigmatizada. (Dumitrescu, 2014: 27-28)

When discussing the popular Spanish of the United States, Otheguy and Stern (2010: 92) rightly highlight:

It is important to recognize the mastery of the Spanish system that underlies these phrases, in which speakers reveal their capacity to speak perfect popular Spanish while expressing the broader US cultural reality of which they are a part.

Furthermore, these authors emphasize:

[...] the fact that Spanish speakers in the USA are frequently also English speakers, and thus have an intimate connection with the conceptualizations of English speakers that leads them to exploit the resources of Spanish in this novel way. In a comparison with Spain or Latin America, this is a cultural, conceptual, or communicative difference, but not a linguistic one, as the language itself has not changed. (Otheguy and Stern, 2010: 92)

\footnotetext{
${ }^{1}$ In their Nuevo Diccionario de Anglicismos, F. Rodríguez and A. Lillo-Buades (1997: 470) define Spanglish as "Variedad de español obtenida por influencia del inglés en zonas donde existe un gran contacto entre ambas lenguas", and note that "Se refiere especialmente al español del sudoeste de Estados Unidos y al de Puerto Rico, a menudo con un sentido peyorativo. También se utiliza para designar el español muy defectuoso que emplean los anglófonos en las primeras etapas de su aprendizaje”.

${ }^{2}$ López García, Ángel (2013b). "Detranslation: Spanglish from a neurolinguistic point of view”, CLAC, 56, 2013, http://www.ucm.es/info/circulo

${ }^{3}$ López García-Molins and Morant-Marco (2015: 86): "El spanglish es un tema controvertido con muchos matices. Hay gente que lo considera una deformación del español y gente que lo considera un símbolo de la identidad latina en los EE.UU.”
} 
Lastly, López García-Molins (2015: 48) further develops the definition by adding the socio-cultural context in which Spanglish is used: "El spanglish es una práctica lingüística mediante la cual los latinos de EE.UU. expresan su orgullo y cohesión grupal.” As Paez (2001: 158) notes, an author may use Spanglish strategically to characterize the individuals in the story, and in this case Piña-Rosales defines his character, Sancho, using this linguistic phenomenon to represent his belonging to the wellestablished, first generation of the Puerto Rican community in New York. ${ }^{4}$ Therefore, it is through this research that we aim to further analyze this phenomenon, and to offer a classification of the Spanglish found in the dialogues of Sancho in the short story, "Don Quijote en Manhattan” (Piña Rosales, 2005 and 2006). In the following we will describe the materials and methodology used for the study, and then the results of the classification proposed and the conclusions drawn.

\section{Materials and Methodology}

The first step of our research involved comparing and contrasting the three versions of Piña Rosales' work (2005, 2006a and 2006b). The 2005 version is somewhat shorter than the 2006 ones, specifically it does not include as many introductory details regarding Ergardo or Heraldo's background (e.g., the bookstore in Union Square) nor does it relate Don Quijote's visit to the Cloisters, his adventures with Sancho at St. John the Divine's, their meeting with the Argentinean students in Central Park, or the episode with the monkeys in the zoo. By contrast, there were very few differences found between the two 2006 versions of the story; therefore, for this study and as the 2006a version could only be obtained through an interlibrary loan from the Biblioteca Nacional de España, we decided to make use of the version available on the internet (2006b). This also facilitated the creation of the sample for study.

The second step of this research involved isolating the 123 instances of dialogue in the story. Sixtythree instances corresponded to Don Quijote, twenty-six were attributed to Sancho and the final thirtyfour were spoken by the other characters: Robber, 2; Padre O’Connor, 2; Argentinos, 2; Zookeeper, 1; Security guard, 2; Homeless man, 7; Bryant Park detainees, 4; Policemen, 3; Twin Towers terrorist, 6; Policemen, 2; Mayor Giuliani, 3. Once the dialogues were identified, we manually extracted the 26 instances of Sancho's dialogue and found that 21 contained code switches.

The final step of the study involved classifying the instances of Sancho's dialogue and the results are presented in the following section.

\section{Results and Discussion}

When analyzing "Don Quijote en Manhattan", we found the discourse to be sprinkled with loanwords, calques and idiomatic expressions from English. For this study, therefore, we identified the 123 instances of dialogue, classified those containing elements from English and examined the distinguishing features of code switching in the story. We find that Sancho's dialogue can be classified according to the type of borrowing, the type of code switching and the possible explanations for the mixing of the two languages.

First, the findings illustrate how, for example, the author strategically interlards Sancho's speech with English loanwords (anyway, chance, cop, hamburguer, human beings, jail, maybe, mess, shelter,

\footnotetext{
${ }^{4}$ According to Paez (2001: 158), a character may be depicted "por CÓMO HABLA. La forma de hablar particular de las personas es uno de los elementos más definitorios, tanto de su nivel cultural, como de su origen GEOGRÁFICO. El modo particular de hablar, su idiolecto o jerga, si está bien conseguido, RETRATA mucho mejor a un personaje, que todo lo que de él podamos decir."
} 
Spanglish, supermarkets). The presence of loanwords is often inevitable, and thus the warning of the author at the beginning of the story:

He intentado que mi escritura sea lo más llana posible, que mis palabras sean más significadas que significantes (aunque no sé si demasiado honestas), evitando caer en anglicismos al uso, tanto en la sintaxis como en el léxico, delicado asunto éste, pues no es fácil sustraerse a esos peligros cuando se llevan, como yo, décadas radicado en un país de lengua inglesa. (Piña Rosales, 2005: 40)

Pure loans are seen in the following instances with spics $^{5}$ and shelter, the first being a concept with no direct equivalent in Spanish, and the latter being coupled with the synonyms asilo and refugio.

- S7 "Llegará un momento en que todos los boricuas dejen la isla y se vengan pa New York, aunque no sé pa qué, pa pasar hambre y que encima los llamen spics.”

- S20 “¿Y por qué no se va a un shelter, a un asilo, a un refugio o como se llame?”

There were two forms found for hamburger in the story, the first in Sancho's dialogue (S10): "Yo me contentaría con una hamburguer y una cervecita" and later as part of the narrator's discourse: "Compró Sancho una hamburguesa, un pretzel y hasta unas papas fritas en un puestecillo ambulante". Variations in forms and codes were also detected when Sancho makes reference to the city of New York; early in the story he uses the English name (as seen above in S7) and later on, the Spanish Nueva York:

- $\quad$ S15 “[...] es mejor que el que come mucha gente en Nueva York, que hasta tienen que andar buscando algo que llevarse a la boca en los zafacones de basura de los supermarkets."

Curiously, Sancho uses the English Spanish in a Spanish sentence to describe the language he spoke with the pet monkey, and later he refers to his use of spanglish, when admitting to Don Quijote that it 'sometimes slips out of him':

- $\quad$ S13 “[...] yo creo que lo [el mono] habían traído de Brasil, porque le hablamos en inglés y en Spanish y no nos hacía ni joío caso.”

- S21 "Yo siempre he creído arguyó Sancho— que a eso se le llamaba casco, aunque como a veces se me escapa el spanglish, ya no sé muy bien.”

\footnotetext{
${ }^{5}$ Fernando Martín Pescador (2013: 253) notes the affirmation by Ilan Stavansen from Mr Spic Goes to Washington: "Spic" es un término peyorativo para referirse a los hispanohablantes en Estados Unidos pues éstos normalmente no distinguen entre el sonido largo y breve de la /i/ en inglés y por lo tanto pronuncian /spik/ en vez de /spi:k/ la palabra speak, que significa hablar" (Berkeley, Soft Skull Press; 2008: 75). The Merriam-Webster’s Learner’s Dictionary defines spic, informal and offensive, as "a person who is a native Spanish-speaker or whose family is from a Spanish-speaking country" and advises avoiding its use (http://www.learnersdictionary.com/definition/spic, consulted 05/05/2016).
} 
Regarding semantic calques, we find college (with the meaning of university) ${ }^{6}$ and indios ${ }^{7}$ (with meaning of Native Americans), the English meaning being extended to the Spanish term, and both representing clear reflections of American culture and history:

- S3 “[...], pero sólo por ver si encuentro mi chance de hacerme rico, y así poder pagar el college a mis tres hijos."

- S7 “¿Pero antes que los hispanos, estaban los indios, no?”

Another semantic extension is found with the use of proyectos (< projects, as in low income housing), in this case Sancho lamenting US influence on the Puerto Rican landscape:

- $\quad$ S7 “[...] ahora no hay más que caseríos, lo que aquí llamamos proyectos, y miseria y na más que miseria."

Interesting too is example of the calquing of lunch, as a mid-day meal, being adapted to the Spanish spelling, as lonche:

- $\quad$ S15 "See, see, señor Quijote, fíjese qué bien los tratan; [...] ese lonche es mejor que el que come mucha gente en Nueva York, [...]"

Finally, we identified one phraseological calque, Hell's Angel > ángel (del Infierno) ${ }^{8}$; in this example, Sancho makes reference to the motorbike rider with the Spanish ángel:

- S24 “¿Bicho? —exclamó Sancho- Ay bendito, ¿le ha cortado usted el bicho al ángel ese?”

According to López García-Molins (2015: 106), code switching consists of joining “fragmentos de discurso pertenecientes alternativamente a una u otra lengua". Therefore, the Spanglish used by Sancho can also be classified according to how the fragments of discourse are connected, in other words, intersentential or intrasentential code switching in one conversational turn. In the following example of intersentential code switching, Sancho changes languages between sentences, one sentence in this case, being in English and the following in Spanish:

- S6 "And how is that? Yo no sabía que le habían cambiado el nombre. [...]”

\footnotetext{
${ }^{6}$ The terms college/colegio are false friends. This phenomenon, which refers to "a palabras similares en dos o más lenguas que poseen significado/s diferentes” (Roca Varela, 2011: 80), often leads to errors in expression and misunderstandings. In this case, the term college is sometimes translated to colegio, when "en inglés se utiliza para referirse especialmente a universidades e instituciones de enseñanza superior para alumnos adultos. Colegio, en español, en cambio, se emplea por lo regular para referirse a centros de estudios para menores de edad” (Piña Rosales et al., 2014).

${ }^{7}$ This is a term which is considered by many to be politically incorrect although it is not indicated as such by certain Spanish dictionaries, for example, the DRAE 22. (2012, online; consulted 05/05/2016): “3. adj. se dice del indígena de América, o sea de las Indias Occidentales, al que hoy se considera como descendiente de aquel sin mezcla de otra raza. U. t. c. s." However, in the Oxford English Dictionary (2015, online at www.oed.com; consulted 05/05/2016), we find the following: "The term American Indian has been steadily replaced, esp. In official contexts, by the more recent term Native American. The latter is preferred by some as being a more accurate description [...] American Indian is still widespread in general use, however, partly because it is not normally regarded as offensive by American Indians themselves." This may be why Quijote substitutes the term "indios" for "Native Americans" in the following affirmation: "¿Pero antes que los hispanos, estaban los indios, no?", preguntó con cierta reticencia Sancho. "Por supuesto — corroboró don Quijote—: ellos antes que nadie: los americanos nativos."

${ }^{8}$ The Oxford Online Dictionary offers the following definition for Hell's Angels: "A member of any of a number of gangs ("chapters") of male motorcycle enthusiasts, first formed in California in the 1950s and originally notorious for lawless behavior." (http://www.oxforddictionaries.com/es/definicion/ingles_americano/hell's-angel; consulted 10/06/2016).
} 
With intrasentential code switching, the speaker uses both languages in the same utterance, and each language brings specific elements into the discourse. This type of code switching is more frequent in Sancho's dialogues, as seen in the following with a prepositional phrase (on T.V.), an article and noun (the mess) or a plural noun (human beings):

- S4 "[...] pero sí me acuerdo de haber visto algo sobre el Quijote y su amigo Sancho on T.V."

- S7 "[...] porque hay que ver the mess en que han convertido a Puerto Rico.”

- $\quad$ S19 "Pero, señor, un caballo es un caballo y un hombre es un hombre. Nosotros, los human beings, somos superiores ¿no?”.

There are several examples of intrasentential code switching with more complete ideas. These language shifts naturally obey a series of rules, as noted by Lipski (2004), who makes reference to the changes that take place after "porque", "que”, "y", "pero" and their English equivalents. ${ }^{9}$ In the following, the English phrase is introduced with the adverbial when in $\mathrm{S}^{10}$ while the conjunction $y$ serves to link the Spanish phrase to the end of the sentence in S26:

- S4 "[...] esta tarde, when I had been taking care of business, me voy con usted."

- $\quad$ S26 “ ¡Yes, yes, yes, he is don Quijote y yo soy Sancho, su amigo y compañero de aventuras!”

Another example of intrasentential code switching combines the English confirmation with the Spanish title and proper name, followed by a Spanish imperative:

- S5 “Everything's ready, señor don Quijote. Vámonos ya antes de que me arrepienta.”11

The examples of Spanglish in Sancho's discourse may also be classified according to the possible reasons for the switches with words, phrases or sentences; however, according to Dumitrescu (2014: 27) "[...] no es siempre fácil decidir qué función (o funciones) discursiva(s) particular(es) desempeña en cada caso el cambio de código en la interacción verbal concreta en que se produce, [...]”. Nevertheless, in one curious example, we find the discourse marker anyway being used casually to introduce Sancho's praise for Don Quijote’s bravery, ${ }^{12}$ and a single word like guts being incorporated as a substitute for agallas:

- S2 “Anyway, reconozco que tiene usted guts”.

Likewise, in the following dialogue we see how Sancho switches to English to describe the pet monkey's effect on his children, and then he uses the adverb maybe (S14) perhaps to reflect concession to Don Quijote's hypothesis:

\footnotetext{
${ }^{9}$ Martín Pescador (2013: 268), when discussing this phenomenon, explains that "hay hablantes nativos que cambian de código con naturalidad y sin dejar de respetar la gramática de ambas lenguas por muy difícil que esto parezca y hablantes no nativos que se limitan a cambiar de código en los lugares incorrectos o, como hace Ilan Stavans en su traducción del primer capítulo del Quijote, se dedican a acumular una ocurrencia detrás de otra que obedecen más al ingenio del autor, como ocurría en el caso de Salvador Tío, que a la realidad de la calle.”

${ }^{10}$ In this case it seems that the norm is fulfilled as noted by Triantafilian-Nginios (2011: 122-123): "Hay frecuentes cambios entre la oración principal y la subordinada (No podemos hacer nada porque we don't have the power, No sé porque I never used it, I'm not saying that son chuecos)."

${ }^{11}$ In the version published in Ventana Abierta (Piña-Rosales, 2005), Sancho says: "Let's go antes de que me arrepienta-".

${ }^{12}$ According to Curiel (2015: 183), "El marcador discursivo anyway al igual que el so es de uso común entre los hablantes hispanos que habitan en La Florida.”
} 
- $\quad$ S13 [...] Y los nenes se pusieron a llorar: the monkey scared the shit out of them".

- "El animal tendría más miedo de vosotros que vosotros de él", le aseguró don Quijote.

- S14 "Maybe — siguió Sancho—, pero era un mono de lo más joío.

Furthermore, we find other cases of single words in English being inserted into the Spanish sentence, in these cases, cops and jail are substitutes for policia and cárcel, perhaps because the Spanish equivalents do not correspond to the imminent threats posed in the English-speaking reality:

- S22 “[...] pero vámonos de aquí que allá vienen los cops y la ambulancia”.

- S23 "No, no señor, eso es un robo. Nos meterán en jail a los dos, y ya deben andar buscándonos por lo de los monos".

Sancho also switches codes for emphatic purposes, as seen when he describes his father's abandoning him and his mother, and the effect that had, the English sonofabitch ${ }^{13}$ being used perhaps euphemistically with the marker so introducing the consequential phrase:

- S3 Mi pai era puertorriqueño, del mismísimo San Juan, y eso es sólo lo que sé porque cuando yo era un baby el muy sonofabitch nos abandonó a mi mai y a mí, so I had to work my ass to survive in this city.

Additionally, we identified cases in which the code switching seemed to represent the need to reinforce a request or insist on urgency, or, as in S25, to express the dread of spending the night on Rikers Island, New York City's main jail complex:

- $\quad$ S18 “iDon’t you dare, ni se le ocurra!”

- S25 "Por lo que más quiera, señor don Quijote, let's get out of here, que nos van a reconocer por lo de los monos o por lo de la moto y entonces esta noche vamos a dormir en Rikers Island".

Likewise, in their first encounter, for example, Sancho switches to English to express his indignation and disbelief that Don Quijote allowed the thief to go free:

- S1 “¿Pobre hombre? dijo el bodeguero- ¿A ese criminal le llama usted pobre hombre? Pues sepa usted que no es la primera vez que me roba. ¡I don’t believe it!: ¡Y lo ha dejado escapar!”

A final case of interest is seen in the following exchange, when Sancho again expresses indignation and Don Quijote requests that Sancho speak to him in Spanish, Sancho immediately provides an exact translation, effectively demonstrating his mastery of the two languages:

- S16 “iYou are crazy, man, you are crazy! What did you do that for?”

- "En cristiano, Sancho, habla en cristiano — -le replicó don Quijote—, en mi lengua, que es la tuya".

• S17 “¡Pero se ha vuelto usted loco! ¡A quién se le ocurre hacer una cosa así!”, dijo Sancho.

\footnotetext{
${ }^{13}$ In his novel Los amores y desamores de Camila candelaria, Piña Rosales (2014: 21) substitutes the swear word in Spanish for the English with a euphemistic intention: "Pero no te preocupes, que para eso están los abortos, aunque sean ilegales”. "¡Son of a bitch!”.
} 


\section{Conclusions}

As we celebrate the 400-year anniversary of Cervantes' death and the publication of the second part of El ingenioso hidalgo don Quijote de La Mancha, we believe that Piña-Rosales' "Don Quijote en Manhattan” (2005 and 2006a/b) is ideal for sociolinguistic and interdisciplinary studies of Spanglish. The author affirms his aim in writing this story: "quise divertirme y divertir" (Morant-Marco, 2016); therefore, we may consider Sancho's language as representative of one member of the multicultural, bilingual speech community in the USA. This small corpus analysis aimed to offer insight into the intricacy and complexity of Spanglish and, as Lipski (2004) recommended, to shed light on its characterization, specifically, who speaks it, when it is used and how this remarkable linguistic and cultural phenomenon is created and constructed. Our results provide evidence of how Sancho's Spanglish is constructed with loanwords (pure and adapted) and calques (semantic and phraseological) as well as how intersentential and intrasentential code switching occurs. Finally, future studies should continue to enhance our knowledge and promote the recognition of Spanglish, as a unique discursive practice and an intricate symbol of identity for its speakers, especially among professionals and academics, such as those represented in the Spanish Society of Applied Linguistics.

\section{References}

Betti, S. (2008). El Spanglish ¿medio eficaz de comunicación? Bologna: Pitagora Editrice Bologna.

Betti, S. (2015). “Español en/de los Estados Unidos: ¿español estadounidense o spanglish?”, in S. Betti and D. Jorques (eds.), 12-25.

Betti, S. and Jorques, D. (eds.). (2015). Visiones europeas del Spanglish. Valencia: Uno y Cero Ediciones.

Curiel, B. (2015). Análisis discursivo del español hablado en la Florida a través del chat. Universidad de Córdoba, Doctoral Thesis.

Dumitrescu, D. (2013). “Lo que es y lo que no es. Una nota sobre el spanglish”, RANLE, Vol. 2-4, 353-361.

Dumitrescu, D. (2014). "La alternancia de lenguas como actividad de imagen en el discurso hispanounidense”, $\quad$ Pragmática sociocultural, Vol. 2 (Gruyter). See http://www.hispanismo.es/revista.asp?DOCN=4881 [Retrieved 09/09/2015]

Dumitrescu, D. (2015). “Spanglish, estadounidismos y bilingüismo vestigial”, in S. Betti and D. Jorques (eds.), 26-40.

Lipski, J.M. (2004). "Is "Spanglish” the third language of the South?: truth and fantasy about U.S. Spanish”, Lecture given at LAVIS-III, University of Alabama, Tuscaloosa, April 16, 2004, 27 pgs., <http://personal.psu.edu/jml34/spanglsh.pdf> [Retrieved 09/09/2015]

López García-Molins, Á. (2015). Teoría del Spanglish. Valencia: Tirant Humanidades.

López García-Molins, Á. (2016, forthcoming). “El Spanglish como dialecto psicológico”.

López García-Molins, Á. and Morant-Marco, R. (2015). "El spanglish como fundamento del nacionalismo latino en EE.UU”, in S. Betti and D. Jorques (eds.), 86-95.

Martín Pescador, F. (2013). El bilingüismo en el estado de Nuevo México: pasado y presente. Universidad Nacional de Educación a Distancia, Doctoral Thesis, <http://espacio.uned.es/fez/view/tesisuned:Filologia-Fmartin> [Retrieved 15/07/2015]

Morant-Marco, R. (2016, forthcoming). “Entrevista a Gerardo Piña Rosales”, RANLE-Revista de North American Academy of the Spanish Language (Washington, D.C.).

Otheguy, R. and Stern, N. (2010). “On so-called Spanglish”, International Journal of Bilingualism, 15-1, 85-100. http://www.anle.us/usr/docs/on-so-called-spanglish.pdf [Retrieved 24/07/2015]

Paez, E. (2001). Escribir. Manual de técnicas narrativas. Madrid: SM. 
Piña Rosales, G. (2005). “Don Quijote en Manhattan”, Ventana Abierta (University of California, Santa Barbara), Vol. V, 19, 39-50.

Piña Rosales, G. (2006a). "Don Quijote en Manhattan”, In Seis Narradores españoles en Nueva York. Granada: Dauro ASB Ediciones (Colección Alminares, No. 7), 47-74.

Piña Rosales, G. (2006b). "Don Quijote en Manhattan”, <https://goo.gl/anPbkx> [Retrieved 05/05/2015]

Piña Rosales, G. (2014). Los amores y desamores de Camila candelaria. Houston (TX): Literal Publishing.

Piña Rosales, G., Covarubias, J.L. and Dumitrescu, D. (eds.) (2014). Hablando bien se entiende la gente 2. New York: ANLE-Aguilar.

Roca Varela, M.L. (2011). "Teaching and learning "false friends": a review of some useful resources", Encuentro: revista de investigación e innovación en la clase de idiomas (Universidad de Alcalá), No 20, 80-87.

Rodríguez González, F. (Director) and Lillo Buades, A. (1997). Nuevo Diccionario de Anglicismos. Madrid: Gredos.

Triantafilian-Nginios, Rosa (2011). “Sobre el spanglish en los Estados Unidos”, Tinkuy - Boletín de investigación y debate (Université de Montréal), Vol. 15, 118-126.

Zentella, A.C. (1997). Growing Up Bilingual: Puerto Rican Children in New York. Oxford (UK): Blackwell Publishers. 